\title{
Effect of Population Proportion of Component Crops on Growth, Yield and Nutrient Uptake of Component Crops in Maize+Soybean Intercropping
}

\author{
S. G. Telkar ${ }^{1 *}$, A. K. Singh ${ }^{2}$ and Joy Kumar Dey ${ }^{3}$
}

${ }^{1 \& 2}$ Dept. of Agronomy, at College of Post Graduate Studies (CAU-I), Umiam (793 103), India

${ }^{3}$ Dept. of Agronomy, Institute of Agriculture, Visva-Bharti, Sriniketan, West Bengal (731 235), India

\section{Corresponding Author}

S. G. Telkar

e-mail: telkarshivkumar53@gmail.com

\author{
Article History \\ Article ID: $3 \mathrm{C0363}$ \\ Received in $6^{\text {th }}$ October, 2017 \\ Received in revised form $28^{\text {th }}$ November, 2017 \\ Accepted in final form $5^{\text {th }}$ December, 2017
}

\begin{abstract}
A field experiment was conducted during Kharif 2016 at CPGS, CAU, Umiam, Meghalaya. The soil was sandy clay loam in texture, moderately acidic in reaction ( $\mathrm{pH}$ 5.23), high in soil organic carbon (1.02 \%) and medium in available N, P and K (315.04, 16.34 and $196.12 \mathrm{~kg}^{-1}$, respectively). The experiment consist of eight treatments such as sole maize, sole soybean, 1:1replacement, 1:1additive, 2:1replacement, 2:1additive, 2:1paired and 2:2paired) replicated thrice in randomized block design. Sole maize recorded significantly higher yield attributes such as cob weight plant ${ }^{-1}$, grains cob $^{-1}$ and grain weight plant ${ }^{-1}$ which was at par with 1:1Replacement but significantly superior over the all other treatments. However, 1:1Replacement for soybean recorded significantly higher yield attributes such as no. pods plant ${ }^{-1}$ and pod weight plant ${ }^{-1}$ which was at par with sole soybean and 2:1Replacement, 2:2Paired and 2:1Paired but significantly superior over the 1:1Additive and 2:1Additive. Among the intercropping treatments, significantly higher grain yield of maize recorded from 2:1Additive over grain yield recorded from all other intercropping except 2:1Replacement. In soybean, 1:1Replacement recorded significantly higher grain yield over all other intercropping treatments except 2:2Paired. Among the intercropping treatments, significantly lower $\mathrm{N}, \mathrm{P}$ and $\mathrm{K}$ uptake by 1:1Replacement of maize than 2:1Additive, 2:1Replacement and 2:1Paired intercropping treatments. However, 1:1Replacement of soybean recorded significantly higher $\mathrm{N}, \mathrm{P}$ and $\mathrm{K}$ uptake over the1:1Additive, 2:1Replacement, 2:1Additive, 2:1Paired and 2:2Paired intercropping treatments. From the results of this study concluded that 1:1Replacement intercropping of maize+soybean was more benefitted than any other intercropping treatments.
\end{abstract}

Keywords: Additive, intercropping, maize, nutrient uptake, replacement, soybean

\section{Introduction}

Maize (Zea mays L.) is the second most important crop of North-East Hill region (NEH) after rice (Das et al., 2010). It accounts $2.65 \%$ and $1.52 \%$ of total area and production of country, respectively. However, productivity of maize much below than the national average productivity. Soybean is a ruling grain legume crop in NEH region accounts $17.59 \%$ and $13.92 \%$ of total area and production of the country, respectively (Anonymous, 2014). The yield of crop is governed by number of factors soil type, optimum plant population, balanced nutrition. The extent of competition-induced yield losses of component crops in intercropping is likely to depend on their spatial arrangement (Undies et al., 2012). The fertilizer application in NEH region is very meager in comparison to other parts of the country. In one side, being a legume, soybean crop offers good potential to fix free atmospheric $\mathrm{N}\left(80-350 \mathrm{~kg} \mathrm{ha}^{-1}\right)$ in the soil and also helps in the improving $\mathrm{P}$ availability in the soil and other side it offers good scope for crop intensification of wide spaced grown maize based production systems through appropriate planting pattern (Choudhary, 2015). Planting pattern is one of the important agronomic approaches in various intercropping systems. Cereal-legume based intercropping system can play vital role in subsistence food production in uplands of the region (Yogesh et al., 2014).

\section{Materials and Methods}

A field experiment was conducted during Kharif season of 2016 at Experimental Farm of College of Post-Graduate Studies, CAU, Umiam, Meghalaya. The soil was sandy clay loam in texture, moderately acidic in reaction, high in organic carbon $1.02 \%$, medium in available N, P and $\mathrm{K} 315.04,16.34$ and $196.12 \mathrm{~kg} \mathrm{ha}^{-1}$, respectively. The experiment consists of 8 treatments $\left(T_{1}\right.$-sole maize $[60 \mathrm{~cm} \times 20 \mathrm{~cm}], T_{2}$-sole soybean [30 cm x10 cm], $T_{3}$-maize+soybean 1:1 replacement series, $\mathrm{T}_{4}$-maize+soybean 1:1 additive series, $\mathrm{T}_{5}$-maize+soybean 2:1 replacement series, $\mathrm{T}_{6}$-maize+soybean 2:1 additive series, 
$\mathrm{T}_{7}$-maize+soybean 2:1 paired row and $\mathrm{T}_{8}$-maize+soybean 2:2 paired row). The experiment was laid out in three times replicated by randomized block design (RBD). DA-61-A maize and JS-335soybean were used as test crop. The soil was brought to fine tilth condition by 2-3 ploughings with power-tiller. Both crops were sown simultaneously in last week of June, 2016. Recommended dose of NPK (80:60:40 and 20:60:40 kg ha-1) was used for maize and soybean, respectively. The half dose of NPK for maize and full dose of NPK for soybean was applied as basal. The half dose of remaining $\mathrm{N}$ was applied into two equal splits at 30 and 55 days after sowing (DAS). And other recommended packages and practices were followed during the growing period of the crops and harvested in order on $4^{\text {th }}$ and $20^{\text {th }}$ October, 2016. All the observations were measured as per the standard procedures. Data statistically analyzed by using the technique of analysis of variance and difference between the treatment means was tested as to their statistical significance with appropriate critical difference value at $5 \%$ level of probability (Gomez and Gomez, 1984).

\section{Results and Discussion}

\subsection{Growth Parameters}

The growth parameters of maize and soybean were measured in terms of plant height, leaf area and leaf area index (LAI) of plant at various growth stages (Table 1 and Table 2). The parameters such as plant height and dry matter were found to have an increasing trend with the advancement of crop growth and maximum value of them was attained at harvest stage. However, leaf area and LAl in both the crops had an increasing trend only upto 60 DAS and a decline was observed till harvest irrespective to the treatment. At all stages of observation, maize plant height (table 1) did not vary significantly however slightly more plant height was recorded in 2:1P row planting population of maize with soybean over the other sole and intercropping treatments. The lack of marked difference in plant height of maize is probably due to the absence of significant competition for light as a result of intercropping with soybean. Similar results also reported by Muoneke et al. (2007), Singh et al. (2008) and Undies et al. (2012) they found that no significant differences in terms of plant height, between sole maize and intercropped maize with soybean. However in soybean, a significance difference for plant height among treatments was observed at harvest stage. At all stages of observation soybean plant height was more in 1:1A planting population followed by 2:2P row planting which was possibly due to higher competition among the plants for utilizing vertical space for better utilization of light that was a limiting factor because of shading by maize canopy. Muoneke et al. (2007) and Singh et al. (2008) also reported competition for light in narrow spaced crop that resulted in taller plants. At all stages of observations, leaf area (except at 30 DAS) and LAl in maize were relatively higher in 2:1P planting proportion intercropped maize over the sole and other intercropping treatments (Table 1). It was because of better growth of maize plants due to poor competition from intercropped soybean which was planted at $70 \mathrm{~cm}$ wider spacing of $45 \mathrm{~cm}$ from both sides of maize rows. Further, higher LAI in paired row planted maize was because of lesser availability of ground area to individual maize plants as the spacing between two maize rows was only $45 \mathrm{~cm}$ as compare to $60 \mathrm{~cm}$ in normal sole maize. A decline in leaf area after 60 DAS was recorded in both the crops irrespective of the treatments mainly due to leaf senescence. Mandal et al. (2014) also found more number of leaves in maize at 60 DAS. Leaf area and LAI in soybean also differed significantly at all stages due to population proportion of component crops except for leaf area at 30 DAS and the trends in increase of both these parameters were similar to maize with advancement of crop growth. At 60 DAS and harvest stages, significantly higher leaf area in soybean was observed in intercropping treatments $2: 2 \mathrm{P}$, 2:1P and 1:1 $\mathrm{R}$ while LAl at all the stage was significantly higher in 2:2P planting proportion of intercrops (Table 2). This was again because of less availability of ground area to individual soybean plants under 2:2P paired row planting as the space between two soybean rows was $20 \mathrm{~cm}$ only under this treatment as compare to $30 \mathrm{~cm}$ of normal sole maize

Table 1: Effect of various planting patterns on growth parameters of maize crop in maize+soybean inter-cropping system

\begin{tabular}{lccccccccc}
\hline Treatment & \multicolumn{3}{c}{ Plant height in $\mathrm{cm}$} & \multicolumn{3}{c}{ Leaf area $\left(\mathrm{cm}^{2}\right.$ plant $\left.{ }^{-1}\right)$} & \multicolumn{3}{c}{ Leaf area index (LAI) } \\
\cline { 2 - 9 } & 30 DAS & 60 DAS & Harvest & 30 DAS & 60 DAS & Harvest & 30 DAS & 60 DAS & Harvest \\
\hline SM & 73.59 & 167.0 & 192.3 & 3615.34 & 5123.27 & 1229.58 & 3.01 & 4.27 & 1.02 \\
1:1R & 71.95 & 164.9 & 192.1 & 3201.18 & 4425.92 & 1062.22 & 3.56 & 4.92 & 1.18 \\
1:1A & 74.24 & 166.4 & 191.1 & 2743.28 & 3441.05 & 1123.88 & 2.29 & 2.87 & 0.94 \\
$2: 1 \mathrm{R}$ & 70.27 & 161.1 & 187.7 & 2718.13 & 3846.73 & 847.28 & 2.27 & 3.21 & 0.71 \\
$2: 1 \mathrm{~A}$ & 72.83 & 164.6 & 190.0 & 2452.28 & 3763.46 & 752.694 & 2.04 & 3.14 & 0.63 \\
$2: 1 \mathrm{P}$ & 74.85 & 171.9 & 199.2 & 3539.11 & 5150.62 & 1287.65 & 3.93 & 5.72 & 1.43 \\
$2: 2 \mathrm{P}$ & 72.85 & 163.8 & 198.0 & 2618.59 & 3772.74 & 943.18 & 2.91 & 4.19 & 1.05 \\
SEm \pm & 2.46 & 7.00 & 9.07 & 218.38 & 366.71 & 84.73 & 0.24 & 0.33 & 0.08 \\
$\mathrm{CD}(p=0.05)$ & NS & NS & NS & 672.84 & 1129.87 & 261.07 & 0.73 & 1.02 & 0.24 \\
\hline
\end{tabular}




\begin{tabular}{lccccccccc}
\hline Table 2: Effect of various planting patterns on growth parameters of soybean crop in maize+soybean inter-cropping system \\
\hline & \multicolumn{3}{c}{ Tlant height in cm } & \multicolumn{3}{c}{ Leaf area $\left(\mathrm{cm}^{2}\right.$ plant $\left.{ }^{-1}\right)$} & \multicolumn{3}{c}{ Leaf area index (LAl) } \\
\cline { 2 - 10 } & 30 DAS & 60 DAS & Harvest & 30 DAS & 60 DAS & Harvest & 30 DAS & 60 DAS & Harvest \\
\hline SS & 23.17 & 54.01 & 72.19 & 343.95 & 1643.48 & 1359.64 & 1.15 & 5.48 & 4.53 \\
1:1R & 23.68 & 49.37 & 63.95 & 348.11 & 2098.73 & 1483.12 & 0.77 & 4.66 & 3.30 \\
1:1A & 23.91 & 58.95 & 73.93 & 367.82 & 1823.33 & 1177.85 & 1.23 & 6.08 & 3.93 \\
2:1R & 21.35 & 49.23 & 63.30 & 305.41 & 1684.80 & 1368.37 & 0.68 & 3.74 & 3.04 \\
2:1A & 20.53 & 55.07 & 66.75 & 291.72 & 1561.55 & 1462.78 & 0.97 & 5.21 & 4.88 \\
2:1P & 23.75 & 54.25 & 64.38 & 330.39 & 2120.63 & 1878.20 & 0.73 & 4.71 & 4.17 \\
2:2P & 22.69 & 55.48 & 72.59 & 370.06 & 2242.13 & 1918.67 & 1.85 & 11.21 & 9.59 \\
S.E. $(m) \pm$ & 1.51 & 2.74 & 2.26 & 17.24 & 125.23 & 108.26 & 0.05 & 0.38 & 0.39 \\
C.D $(p=0.05)$ & NS & NS & 6.96 & NS & 385.84 & 333.55 & 0.15 & 1.16 & 1.21 \\
\hline
\end{tabular}

SM: sole maize; SS: sole soybean; R: replacement series; A: additive series; P: paired row

in association with relatively higher leaf area among all the treatments (Table 2). Similar results were also reported in intercropping soybean with maize by Undies et al. (2012) and Mandal et al. (2014).

\subsection{Yield attributes and Yields}

Significantly maximum number of cobs plant ${ }^{-1}$ was recorded with $1: 1 \mathrm{R}$, which was statistically at par with sole maize and 2:1R but significantly superior over the other planting patterns (Table 3). Significantly highest difference on number of grains $\mathrm{cob}^{-1}$ was observed with the treatment received sole maize which was at par with 2:1R, 1:1R, 2:2P and 2:1P but statistically higher over the $2: 1 \mathrm{~A}$ and $1: 1 \mathrm{~A}$. Sole maize recorded maximum grains weight $\mathrm{cob}^{-1}$ which was at par with 2:1R, 1:1R and 2:1P. There was no significant difference found on shelling percentage however, relatively higher values obtained from 2:1R than other planting patterns. Significantly higher difference on test weight was obtained with treatment sole maize which was at par with 2:1R and $1: 1 \mathrm{R}$ but statistically superior over the others. The increase in yield attributes in intercropped maize was probably due to more availability of the most limited $\mathrm{N}$ and $\mathrm{P}$ nutrition at the time of grain filling and its effective utilization possibly by harnessing legume effect which resulted in an increase in sink capacity and nutrient uptake by the crop. Sole maize recorded maximum grain yield $\left(3.12 \mathrm{t} \mathrm{ha}^{-1}\right)$ which was statistically at par with 2:1A and 2:1R but significantly superior over the grain yield recorded from all other intercropping treatments of maize with soybean. Maize grain yield recorded from 2:1A intercropping treatment was also significantly higher over

Table 3: Effect of various planting patterns on yield attributes of maize and soybean crop in maize+soybean inter-cropping system

\begin{tabular}{|c|c|c|c|c|c|c|c|c|c|c|c|c|c|}
\hline \multirow[t]{2}{*}{ Treatments } & \multicolumn{6}{|c|}{ Maize } & \multicolumn{7}{|c|}{ Soybean } \\
\hline & $\mathrm{CP}$ & GC & GWC & $S$ & $\begin{array}{l}\text { Test wt. } \\
\text { (g) }\end{array}$ & GY & $\begin{array}{l}\text { Pod } \\
\text { plant }^{-1}\end{array}$ & $\begin{array}{l}\text { Grains } \\
\text { pod }^{-1}\end{array}$ & $\begin{array}{l}\text { Pod wt. } \\
\text { plant }^{-1}\end{array}$ & $\begin{array}{l}\text { Grain wt. } \\
\text { plant }^{-1}\end{array}$ & $S$ & $\begin{array}{c}\text { Test } \\
\text { wt. (g) }\end{array}$ & GY \\
\hline SM & 1.4 & 343.4 & 85.0 & 85.1 & 268.8 & 3.12 & - & - & - & - & - & - & - \\
\hline SS & - & - & - & - & - & - & 53.8 & 2.1 & 12.4 & 8.7 & 69.8 & 99.6 & 1.64 \\
\hline $1: 1 \mathrm{R}$ & 1.5 & 334.0 & 72.6 & 86.1 & 257.9 & 1.88 & 62.9 & 2.2 & 15.9 & 11.0 & 69.8 & 108.2 & 0.94 \\
\hline 1:1 A & 1.1 & 259.0 & 49.6 & 83.7 & 211.2 & 2.44 & 47.7 & 2.0 & 11.0 & 7.7 & 70.0 & 94.4 & 0.72 \\
\hline $2: 1 \mathrm{R}$ & 1.3 & 338.4 & 77.0 & 87.9 & 268.2 & 2.67 & 56.5 & 2.3 & 15.0 & 10.7 & 71.1 & 104.4 & 0.42 \\
\hline $2: 1 \mathrm{~A}$ & 1.1 & 281.6 & 61.5 & 87.5 & 236.3 & 3.03 & 38.9 & 2.0 & 9.8 & 7.0 & 71.0 & 101.5 & 0.22 \\
\hline 2:1 P & 1.2 & 314.8 & 68.3 & 87.2 & 213.3 & 2.34 & 52.1 & 2.1 & 13.8 & 9.6 & 70.0 & 105.2 & 0.42 \\
\hline $2: 2 \mathrm{P}$ & 1.1 & 322.2 & 61.8 & 81.8 & 222.1 & 2.26 & 54.7 & 2.1 & 14.9 & 10.6 & 70.6 & 101.4 & 0.81 \\
\hline SEm \pm & 0.10 & 18.20 & 6.90 & 1.40 & 5.80 & 0.22 & 3.90 & 0.10 & 0.80 & 0.60 & 0.60 & 4.40 & 0.05 \\
\hline $\mathrm{CD}(p=0.05)$ & 0.23 & 55.92 & 21.36 & NS & 17.77 & 0.67 & 11.89 & NS & 2.37 & 1.87 & NS & NS & 0.15 \\
\hline
\end{tabular}

CP: CP: Cobs plant ${ }^{-1}$; GC: Grains cob ${ }^{-1}$; GWC: Grain wt. cob $^{-1}$; S: Shelling \%; GY: Grain yield (t ha $\left.{ }^{-1}\right)$; SM: Sole maize; SS: Sole soybean; R: Replacement series; A: Additive series; P: Paired row 
grain yield recorded from all other intercropping treatments except with 2:1R when the difference between the two was at par. The magnitude of yield reduction in terms of percentage for various intercropping treatments was in order of 3.0, 14.4, $22.9,25.1,27.3$ and $39.7 \%$ for the treatments $2: 1 \mathrm{~A}, 2: 1 \mathrm{R}, 1: 1 \mathrm{~A}$, $2: 1 \mathrm{P}, 2: 2 \mathrm{P}$ and $1: 1 \mathrm{R}$, respectively in comparison to sole maize. Similar findings were also reported by Kheroar and Patra, 2014; Yogesh et al., 2014. A significant difference was observed on the number of pods plant ${ }^{-1}$ from 1:1R which was at par with sole soybean and other intercropping treatments except the soybean pods recorded from $1: 1 \mathrm{~A}$ and $2: 1 \mathrm{~A}$ intercrop treatments. Population proportion of component crops in intercropping did not produced significantly variation in grains pod $^{-1}$ but highest value was recorded from 2:1R. Significantly maximum pods weight plant ${ }^{-1}$ and grain weight plant ${ }^{-1}$ was found with treatment $1: 1 \mathrm{R}$ which was at par with $2: 1 \mathrm{R}, 2: 2 \mathrm{P}$ and $2: 1 \mathrm{P}$ but significantly superior other the sole and other intercropping. There was no significant difference observed on shelling percentage and test weight in response to various plating patterns but values ranged from $69.8-71.0 \%$ and 94.44-108.2 g, respectively. Sole soybean recorded maximum grain yield (1.64 t ha-1) which was significantly higher over the grain yield recorded from all the intercropped treatments influenced by population proportion of component crops. Among intercropping, soybean planted in 1:1R treatment recorded second higher grain yields which being at par with 2:2P was also significantly higher than all other intercropping treatments. The magnitude of reduction in grain yields for various intercropping treatments was in order of 43.5, 51.5, 56.6, 74.9, 75.6 and $87.0 \%$, for the treatments $1: 1 \mathrm{R}, 2: 2 \mathrm{P}$, $1: 1 \mathrm{~A}, 2: 1 \mathrm{R}, 2: 1 \mathrm{P}$ and $2: 1 \mathrm{~A}$ respectively, in comparison to sole soybean. Similar results were also found by Meena et al., 2006; Ssekabembe, 2008 and Waktola et al., 2014.

\subsection{Nutrient uptake}

Nutrients uptake especially N, P and K in both maize and soybean crop was significantly influenced by various planting population of the system and the data are presented in (Table 4). Nutrient uptake was varied significantly due to population proportion of component crops in maize+soybean intercropping system. Significantly higher $\mathrm{N}$ uptake in maize was recorded with treatment received 2:2P planting pattern and $1: 1 \mathrm{R}$ but it was at par with all others. The magnitude of reduction of $\mathrm{N}$ uptake in intercrop maize was in order of 1.3, $5.5,6.4,11.7,17.3$ and $38.8 \%$ for the treatments $2: 1 \mathrm{~A}, 2: 1 \mathrm{R}$, $2: 1 \mathrm{P}, 1: 1 \mathrm{~A}, 2: 2 \mathrm{P}$ and $1: 1 \mathrm{R}$ respectively, as compare to sole maize. Sole maize recorded the highest $P$ uptake which was significantly higher over the treatments $1: 1 \mathrm{R}, 1: 1 \mathrm{~A}$ and $2: 2 \mathrm{P}$. Similarly $\mathrm{K}$ uptake by maize was significantly affected due to population proportion of component crops in intercropping. Sole maize recorded significantly higher amount of $\mathrm{K}$ uptake, which was at par with 2:1P, 2:1A and 2:2P but significantly superior over the other treatments. Sole soybean removed maximum amount of $\mathrm{N}$ which was significantly higher than all the intercropping treatments. Among the treatments, $1: 1 \mathrm{R}$ removed maximum $\mathrm{N}$ which being at par with 1:1A but

\begin{tabular}{|c|c|c|c|c|c|c|}
\hline \multirow[t]{2}{*}{ Treatments } & \multicolumn{3}{|c|}{ Maize } & \multicolumn{3}{|c|}{ Soybean } \\
\hline & Nitrogen & Phosphorus & Potassium & Nitrogen & Phosphorus & Potassium \\
\hline SM & 69.2 & 14.2 & 56.2 & - & - & - \\
\hline SS & - & - & - & 143.4 & 12.7 & 31.4 \\
\hline $1: 1 R$ & 42.3 & 8.8 & 29.6 & 68.1 & 6.6 & 12.6 \\
\hline 1:1 A & 61.1 & 10.4 & 42.3 & 60.8 & 4.7 & 10.1 \\
\hline $2: 1 \mathrm{R}$ & 65.3 & 12.5 & 37.6 & 30.9 & 2.7 & 5.3 \\
\hline 2:1 A & 68.3 & 12.0 & 45.2 & 17.0 & 1.4 & 2.9 \\
\hline 2:1 P & 64.0 & 11.7 & 48.7 & 31.0 & 2.8 & 5.6 \\
\hline $2: 2 \mathrm{P}$ & 57.2 & 11.1 & 43.4 & 55.1 & 4.3 & 7.8 \\
\hline SEm \pm & 3.63 & 0.97 & 3.86 & 3.47 & 0.26 & 0.99 \\
\hline C.D $(p=0.05)$ & 11.17 & 3.00 & 11.91 & 10.67 & 0.80 & 3.03 \\
\hline
\end{tabular}

SM: Sole maize; SS: Sole soybean; R: Replacement series; A: Additive series; P: Paired row

significantly superior over the others. $\mathrm{N}$ uptake from the treatment $1: 1 \mathrm{~A}$ was at par with $2: 2 \mathrm{P}$ but significantly superior to remaining intercrop treatments. Soybean was intercropped with 2:2P also recorded significantly higher $\mathrm{N}$ uptake over the treatments $2: 1 \mathrm{P}, 2: 1 \mathrm{R}$ and $2: 1 \mathrm{~A}$. The magnitude of reduction of $\mathrm{N}$ uptake in intercropped soybean was in order of 52.5, 57.6, $61.6,78.4,78.5$ and $88.1 \%$ with treatments $1: 1 \mathrm{R}, 1: 1 \mathrm{~A}, 2: 2 \mathrm{P}$,
2:1P, 2:1R and 2:1A respectively, as compare to sole soybean. The highest $P$ uptake was found with the treatment received sole soybean, which was significantly higher than others followed by $1: 1 R$. The magnitude of reduction of $P$ uptake was in intercrop soybean in order of 48.1, 62.9, 65.9, 77.9, 78.8 and $88.8 \%$ with the treatments $1: 1 \mathrm{R}, 1: 1 \mathrm{~A}, 2: 2 \mathrm{P}, 2: 1 \mathrm{R}, 2: 1 \mathrm{P}$ and $2: 1 \mathrm{~A}$ respectively, as compare to sole soybean. Significantly 
the highest potassium uptake was observed with sole soybean. Among the different planting patterns significantly highest $\mathrm{K}$ uptake was recorded with treatment received $1: 1 \mathrm{R}$, which was at par with 1:1A but significantly superior over the other planting patterns of the maize-soybean intercropping system. Significant difference among the nutrient uptakes in both intercropped crops might be due to better crop growth, development, sufficient amount supply of $\mathrm{N}$ and $\mathrm{P}$ during the growing period of the crops, higher accumulation of all three primary nutrients in the plant tissues and production of higher dry matter and to a lesser extent only these uptakes were affected by respected nutrient contents. The beneficial effects of different planting patterns on nutrient uptake were also reported by Dawadi and Sah, 2012; Mandal et al., 2014 and Chodhary, 2015.

\section{Conclusion}

In maize+soybean intercropping significantly higher values of maize yield attributes were recorded with sole maize which was at par with 1:1R however, it was superior to other treatments. While number of cobs plant ${ }^{-1}$ recorded with 1:1R which was at par with sole maize. In soybean significantly higher yield attributes recorded with 1:1R than other treatments. Higher amount of nutrient uptake was found with sole planting of the both crops. From the results concluded that 1:1Replacement intercropping of maize+soybean was more benefitted than any other intercropping treatments.

\section{Acknowledgement}

Authors are highly thankful to the Natural Resource Management, CPGS, CAU, Umiam, Meghalaya for providing all necessary help during the experimentation.

\section{References}

Anonymous, 2014. Agricultural Statistics at a Glance. Directorate of Economics and Statistics Ministry of Agriculture, Government of India, New Delhi.

Choudhary, V.K., 2015. Suitability of maize-legume intercrops with optimum row ratio in mid hills of Eastern Himalaya, India. SAARC Journal of Agricultural 12(2), 52-62.

Das, A., Patel, P.D., Munda, G.C., Ghosh, P.K., 2010. Effect of organic and inorganic sources of nutrients on yield, nutrient uptake and soil fertility of maize (Zea mays)mustard (Brassica compestris) cropping systems. Indian Journal of Agricultural Sciences 80, 85-88.

Dawadi, D.R. and Sah, S.K., 2012. Growth and yield of hybrid maize in relation to planting density and nitrogen levels during winter season in Nepal. Tropical Agricultural Research 23(3), 218-227.
Gomez, K.A., Gomez, A.A., 1984. Statistical procedure for agricultural research. An International Rice Research Institute Book, Willey International Science Publication, John Wiley and Sons Inc. New York, United States of America, 1-688.

Kheroar, S., Patra, B.C., 2014. Productivity of maize-legume intercropping systems under rainfed situation. African Journal of Agricultural Research 9(20), 1610-1617.

Mandal, M.K., Baneerjee, M., Baneerjee, H., Pathak, A. and Das, R., 2014. Evaluation of cereal-legume intercropping systems through productivity and competition ability during kharif season in West Bengal. Asian Journal of Science and Technology 5(3), 233-237.

Meena, O.P., Gaur, B.L., Singh, P., 2006. Effect of row ratio and fertility levels on productivity, economics and nutrient uptake in maize (Zea mays)+soybean (Glycine max) intercropping system. Indian Journal of Agronomy 51(3), 178-182.

Muoneke, C.O., Ogwuche, M.A.O., Kalu, B.A., 2007. Effect of maize planting density on performance of maizesoybean intercropping system in guinea savannah agro ecosystem. African Journal of Agricultural Research 2(12), 667-677.

Ssekabembe, C.K., 2008. Effect of proportion of component species on the productivity of Solanum aethiopicum and Amaranthus viridus under intercropping. African Journal of Agricultural Research 3(7), 510-519.

Singh, U., Saad, A.A., Singh, S.R., 2008. Production potential, biological feasibility and economic viability of maizebased intercropping systems under rainfed conditions of Kashmir valley. Indian Journal of Agricultural Sciences 78(12), 1023-1027.

Undies, U.L., Uwah, D.F., Attoe, E.E., 2012. Growth and development of late season maize+soybean intercropping in response to nitrogen and crop arrangement in the forest agro-ecology of South Southern Nigeria. International Journal of Agricultural Sciences 7(1), 1-16.

Waktola, S.K., Belete, K., Tana, T., 2014. Productivity evaluation of maize-soybean intercropping system under rain fed condition at Bench-Maji Zone, Ethiopia. Journal of Agricultural Research 3(9), 158-164.

Yogesh, S., Halikatti, S.I., Hiremath, S.M., Potdar, M.P., Harlapur, S.I. and Venkatesh, H., 2014. Light use efficiency, productivity and profitability of maize and soybean intercropping as influenced by planting geometry and row proportion. Karnataka Journal of Agricultural Science 27(1), 1-4. 